Проценко В.А., Бабий М.В., Настасенко В.А., Белоконь А.О.

НАПРАВЛЕНИЯ И РЕЗЕРВЫ ПОВЫШЕНИЯ ТЕХНИЧЕСКОГО УРОВНЯ РУЛЕВЫХ МАШИН ПЛУНЖЕРНОГО ТИПА С ТАНГЕНСНЫМ МЕХАНИЗМОМ

Статья касается наиьолее распространенного типа судовых гидравлических рулевых машин (ГРМ) плунжерного типа, оснащенных тангенсным рычажным механизмом. Показано, что источником недостатков рулевых машины плунжерного типа является несовершенство рычажной системы, среди них, в частности, ее низкий КПД, высокая нагруженность деталей и наличие значительного количества избыточных связей. Целью работы является установление основных направлений и оценка резервов повышения технического уровня механизма ГРМ плунжерного типа. Задачи работь состоят в следующем: определить основные критерии технического уровня механизма ГРМ плунжерного типа, учитывающих соаершенство структуры, энергетическую эффективность работы, а также нагруженность деталей; выполнить оценку этих критериев для распространенных конструкций ГРМ плунжерного типа; наметить направления повышения технического уровня механизма ГРМ плунжерного типа и оценить резервы их применения. Для разгрузки плунжеров и уплотнений гидрочилиндров от поперечных сил применяют направляющие, которые соединяются с плунжерами низшими кинематическими парами. Это обеспечивает наличие в механизме ГРМ $q=20$ избыточных связей, исключающих возможность самоустановки звеньев механизма. Резервом для уменьшения количества избыточных связей является отказ от направляюших и повышение класса кинематических пар механизма ГРМ. В результате исследований на примере машинь nрототипа YOOWON-MITSUBISHI YDFT-335-2 показано, что в ней обеспечивается возникновение значительных поперечных сил, передаюшихся от румпеля на плунжеры $и$ направляюшие и достигающих около 53\% от окружных усилий на румпеле. Для разгрузки плунжеров и уплотнений гидрочилиндров и поперечных сил применяют направляющие, способные воспринять только 5...7\% поперечного усилия. Потери на трение плунжеров в уплотнениях среди всех механических потерь составляют 39\%. Показано, что повышение технического уровня ГРМ, в частности структурного совершенства, энергетической эффективности и снижения нагруженности деталей, имеет своим ключем замену тангенсного рычажного механизма, преобразующего поступательное движение плунжеров во вращзательное движение румпеля на другой.

Ключевые слова: рулевая машина плунжерного типа, плунжер, направляющая, румпель, момент, поперечная сила, распределение нагрузки, деформация, коэффициент полезного действия, структура. 
Кучерук Г.Ю., Шапіро Г.В., Ткаченко В.В.

\section{РОЗРОБКА АДАПТИВНОЇ СИСТЕМИ КЕРУВАННЯ РУХОМ СУДНА}

В статті запропоновано підхід руху судна на основні оцінювання результатів текучих параметрів руху та аналізу інформації про стан містоположення за допомогою адаптивних систем керування. На ряду з описом технічного рішення системи керування судном висвітлюються позитивні та негативні властивості при побудові адаптивної системи. Також в праці висвітлюється умови роботи адаптивної системи керування судном.

Метою даної статті є розглянути можливість побудови адаптивних систем керування судном в складних умовах для забезпечення безпеки судноводіння

В статті обтрунтовано схема адаптивної системи керування судном для безпосередньої експлуатаиії в умовах тривалого морського плавання та інтенсивної роботи. Особливістю запропонованої схеми є ведення моделі руху судна та блоків оцінювання $i$ адаптації до зовнішніх впливів для визначення та ведення поправки.

Ключові слова: автоматизована система керування, адаптивна система, керування судном, безпека судноводіння

Вступ. Актуальним питанням розвитку водного транспорту на сьогоднішній день залишається вдосконалення автоматизованої системи управління судном, інтеграція даних від різних навігаційних пристроїв в навігаційно-інформаційному комплексі, а також підвищення якості роботи суднових електроенергетичних систем і енергетичних установок [1]. Сучасні тенденції розробки суднового обладнання орієнтується на створення єдиного інформаційно-керуючого простору судна на основі комплексного управління судном, що дозволить більш точно визначати місцеположення в акваторії для своєчасного маневрування, а також бути інтегрованим до застосування в сучасні навігаційні технології (Е-навігація) [2]. При цьому, впровадження і використання складних обчислювальних комплексів відкрили нові можливості щодо забезпечення своєчасного виконання керуючих впливів [2]. У зв'язку 3 цим, виникає необхідність розробити для застосування єдиного адаптивного комплексу управління судном, який може дозволити не тільки чітко і своєчасно виконувати судові операції з маневрування в обмеженому просторі акваторії, але і як наслідок забезпечити безпеку судноводіння в складних умовах.

Аналіз літератури. Аналітичний огляд аварійних випадків [1, 3] свідчить, що основні причини аварійності суден пов'язані не тільки 3 неправильних виробленим керуючого рішенням, але і з інертними характеристиками суден та не своєчасність відпрацювання автоматики в електроенергетичних систем. При цьому, умови мореплавства в першу чергу пов'язані з суттєвим ускладненням судноплавства в прибережних районах та акваторіях портів, обумовлених зростанням швидкості руху, водотоннажності і розмірів транспортних суден, а також збільшенням загальної кількості $[1,2]$. Крім цього, вивчаються динамічні характеристики і параметричні властивості систем автоматики і людини (яка приймає рішення), що також впливає на динаміку руху судна як ергатичної системи. Тому поряд 3 підвищенням рівня знань керівному складу судна необхідно розуміння процесів руху морським транспортним засобом та судновими технічними засоби керування, у тому числі засобами автоматизації та обміну інформації між ними. Крім того, засоби автоматизації керування судном потребують керуючи засоби адаптивного характеру $[1,3]$. Це пов'язано 3 цім, що виникають ситуації при судноводінні в яких умови руху змінюються в залежності від 
метеорологічних явищ або під іншими обставинами. Необхідність активного розвитку і впровадження технічних засобів автоматизації руху на судах визначається об'єктивними передумовами, такі як: динамічними умовами морської поверхні; розвиток конструктивних матеріалів суднів та методів судноплавства; підвищення параметрів, що пов'язані з точністю судноводіння; інтенсивною розробкою та використанням засобів приладобудування, електроніки і радіоелектроніка, а також спеціальних обчислювальних систем і автоматики. Крім того на сьогодні існують адаптивні авторульові. Однак дані адаптивні системи здійснюють тільки стабілізацію руху судна за заданим курсом. Також недоліком адаптивних авторульових $є$ обмеження судноводіння в акваторіях портів [2, 4]. Тому виникає необхідність розглядати адаптивні системи керування рухом судна як ціле.

Мета статті. Метою даної статті є розглянути можливість побудови адаптивних систем керування судном в складних умовах для забезпечення безпеки судноводіння.

Виклад основного матеріалу. Дослідження літератури $[2,4,5]$ показали, що автоматизація судноводіння пов'язана 3 сукупністю методів i технічних засобів, які забезпечують автоматичне або автоматизоване управління рухом судна. При цьому, судно $\epsilon$ об'єктом управління, а рух по курсу 3 оптимальними параметрами забезпечується за допомогою різних суднових навігаційних пристроїв, які необхідні для управління. Вирішення задач судноводіння є достатньо специфічним, яке характеризується рішенням навігаційних завдань, а також оцінкою морської навігаційної обстановки, яка динамічно змінюється. Тому в сучасних водних транспортних засобах присутні два, три и більше типів навігаційних приладів. Таким чином, адаптивна система управління судном повинна включати не тільки технічні засоби автоматизованого керування електроенергетичних систем і енергетичних установок $[6,7]$, але і суднові засоби навігації, які будуть здійснювати оцінку стійкості руху судна по заданому курсу. Це пов'язано з підвищенням вимог до точності, надійності, оперативності прийняття рішень як при судноводінні, так і при маневруванні судна [3, 4]. Тому необхідно підвищувати якість оцінювання навігаційної параметрів місцеположення для руху судна.

Аналізуючи літературу $[1,2]$, можливо прийти до висновку, що в даний час розробляються і впроваджуються засоби автоматизації судноводіння поділяється на три основні напрямки.

Перший напрямок пов'язано зі складністю алгоритмів автоматизації завдань судноводіння. В даному випадку розробка і впровадження автоматизованих систем навігації і управління судном, найбільш повно і ефективно реалізують основну ідею автоматизації судноводіння - об'єднання навігації з керуванням рухом судна. Завдяки цьому зменшується роль суб'єктивних факторів при виробленні керуючого рішення по управлінню судном в різних умовах плавання, що сприяє підвищенню точності, надійності і економічності судноводіння і як наслідок зменшує появи аварій.

Другий напрямок - використання інформаційно-обчислювальних радіонавігаційних, радіолокаційних і пошукових гідроакустичних приладів і систем. На відміну від першого напряму інформаційно-обчислювальні системи забезпечують тільки автоматизацію вимірювань і обробки різноманітної навігаційної і гідроакустичної інформації. Автоматичне управління судном в таких системах не передбачено.

Третій напрям - застосування спеціалізованих і універсальних ЕОМ для автоматизації вирішення навігаційних, астрономічних і експлуатаційно-технічних завдань. Застосування спеціалізованих ЕОМ використовуються на малих судах. Це пов'язано з масо-габаритними характеристиками. Автоматизація обробки різноманітної судновий інформації за допомогою спеціалізованих і універсальних ЕОМ, хоча і переважно з ручним введенням вихідних даних, звільняє судноводія від обчислень і дозволяє зосередити зусилля на управлінні судном.

Враховуючи вищевикладене, а також аналіз літератури $[3,4,5]$ щодо побудови оптимального курсу з врахуванням зовнішнього впливу розробимо перспективну систему керування рухом судна основним елементом якої є розробка адаптивної системи керування за допомогою оцінювання навігаційної обстановки та обчислювання поправки в системі 
адаптації яка визначається з результатів моделі судноводіння (дивись рис. 1). В свою чергу внесення моделі руху судна 3 теоретичними можливостями автоматизації судноводіння забезпечує розуміння істоти закладених в алгоритм методів управління енергетичними установками, що дозволяє здійснювати контрольоване керування судном в постановці і вирішенні завдань судноводіння за допомогою EOM $[2,3]$. Особливістю моделі також $\epsilon$ вироблення оптимального керування на основі алгоритмів які враховують зовнішні дії.

Найбільш характерними рисами адаптивної системи керування судном $є$ комплексна обробка інформації навігаційних даних від різних засобів в обчислювачах підсистем в спецобчислювачах, а також надання їх в модель руху для автоматичного виявлення зміни курсу судна і керування в цілому. Враховуючи схему побудови системи керування судном $[2,4,5]$, запропонована адаптивна

система керування для водних транспортних засобів основана на оцінюванні отриманих даних і виробленні поправки руху або оптимальної керуючої дії (рис.1). Адаптивна система керування судном здійснює розрахунок оптимальної керуючої дії (поправки руху) на основі здобуття інформації від блока оцінювання і керувань і посилки інформації про навігаційні параметри процесу руху судна, що дозволяє побудувати адаптивну до зовнішніх дій. В даному випадку система адаптивного керування, отримуючи інформацію від блоку оцінювання посилає сигнали на керований об'єкт з можливістю визначення свого стану. Адаптивна система керування судном здійснює керований процес руху судна, а судноводіння за допомогою інформації про вектор стану і параметри моделі керованого процесу, здійснює оптимальне керування цим процесом $[4,5]$.

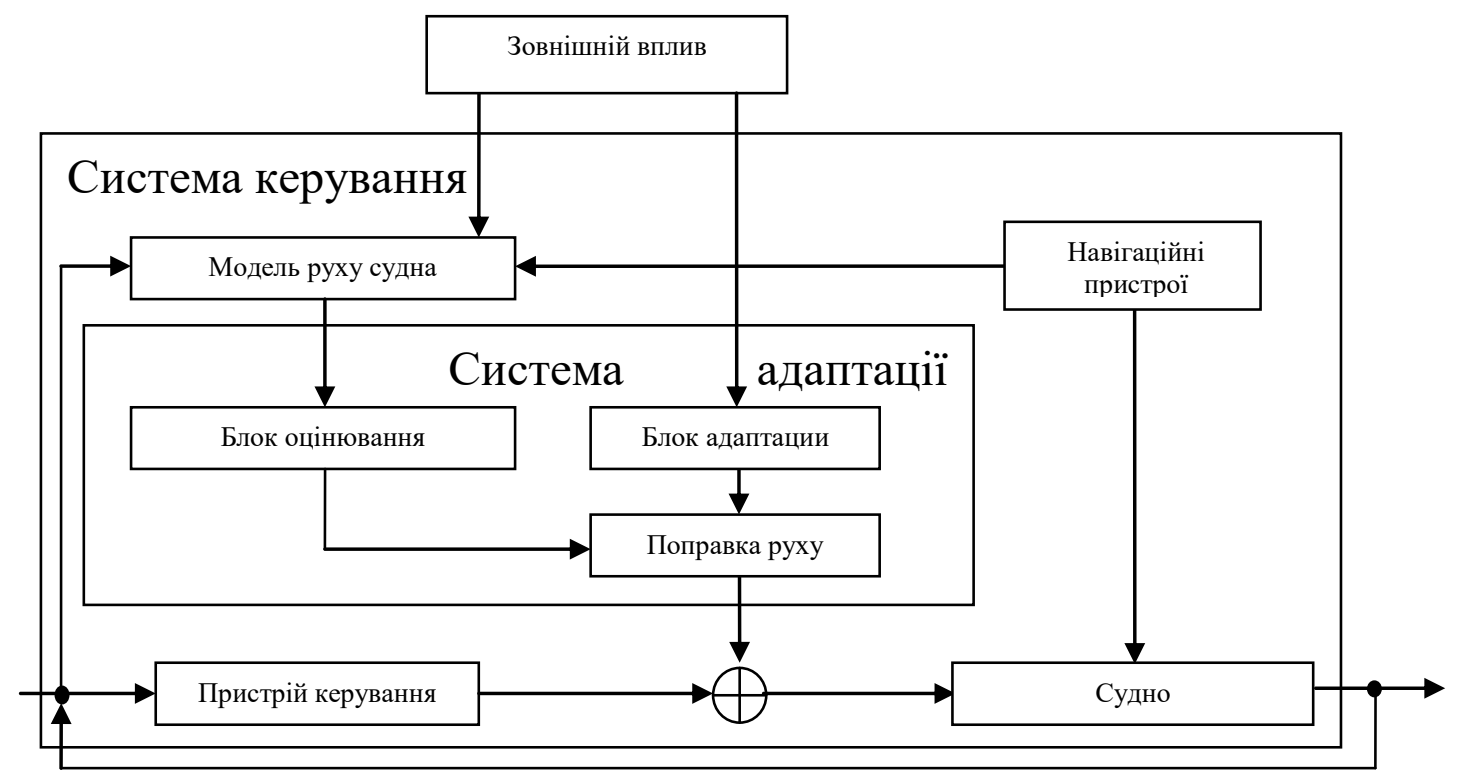

Рисунок 1 - Адаптивна система керування судном

\section{Висновки}

Проблема підвищення безпеки судноводіння є однією з найважливіших завдань, яке можливо вирішити на основі інтеграції силових установок 3 навігаційно-інформаційним комплексом для оптимального керування рухом судна. Вищевикладене показує, що автоматизація судноводіння охоплює досить широке коло питань, в тому числі способи отримання i обробки навігаційної інформації, вибір оптимального шляху плавання, регулювання руху судна по заданому курсу і траєкторії, в процесі маневрування, а також обробка даних від технічних засобів автоматизації управління судном.

Враховує умови використання рухових установок и силових агрегатів судна, які управляються за допомогою їх автоматизації, можливо побудувати нову систему керування адаптовану до зовнішніх факторів. 
В статті обгрунтовано запропонована схема адаптивної системи керування судном для безпосередньої експлуатації в умовах тривалого морського плавання та інтенсивної роботи. Особливістю запропонованої схеми є ведення моделі руху судна та блоків оцінювання i адаптації до зовнішніх впливів для визначення та ведення поправки.

\section{ЛІТЕРАТУРА}

1. Вагущенко Л.Л. Системы автоматического управления движением судна // Л.Л. Вагущенко, Н.Н. Цымбал. - Одесса: Фенікс, 2007. - 328 с.

2. Вагущенко Л.Л. Современные информационные технологии в судовождении / Л.Л. Вагущенко - Одесса: ОНМА, 2013. - 135 с.

3. http://emsa.europa.eu/publications/reports/item/4266-annual-overview-of-marine-casualtiesand-incidents-2020.html.

4. Карасев В.В. Современная система автоматизация судовождения / В.В. Карасев, Н.В. Вовченко. - Владивосток: Дальрыбвтуз, 2005. - 108 с.

5. Власов К.П. Теория автоматического управления / К.П. Власов. - Харьков: Изд-во Гуманитарный центр, 2007. - 526 с.

6. Артемов Г.А. Суднові енергетичні установки / Г.А. Артемов, В.М. Горбов. Миколаїв: УДМТУ, 2002. - 356 с.

7. Носенко В.М. Судовые энергетические установки / В.М. Носенко. - Николаев: ФЛН Швед В.Д., 2013. - 443 с.

\section{Kucheruk G.Yu., Shapiro G.V., Tkachenko V.V.}

\section{DEVELOPMENT OF AN ADAPTIVE CONTROL SYSTEM MOVEMENT OF THE SHIP}

The article proposes an approach to the movement of the vessel for the main estimates of the results of the current parameters of movement and analysis of information about the state of the location using adaptive control systems. Along with the description of the technical solution of the ship control system, positive and negative properties are highlighted in the construction of an adaptive system. The work also highlights the operating conditions of the adaptive ship control system.

Key words: automated control system, adaptive system, ship control, navigation safety

\section{Кучерук Г.Ю., Шапиро Г.В., Ткаченко В.В.}

\section{РАЗРАБОТКА АДАПТИВНОЙ СИСТЕМЫ УПРАВЛЕНИЯ ДВИЖЕНИЕМ СУДНА}

В статье предложен подход движения судна на основные оценки результатов текущих параметров движения и анализа информащии о состоянии местоположения $c$ помощью адаптивных систем управления. На ряду с описанием технического решения системы управления судном освещаются положительные и отрицательные свойства при построении адаптивной системы. Также в работе освещается условия работы адаптивной системы управления судном.

Ключевые слова: автоматизированная система управления, адаптивная система, управление судном, безопасность судовождения 